\title{
Developing Trends in Sri Lankan English (SLE) Vocabulary in the Domain of Journalistic Writing
}

\author{
Nandula Perera \\ Department of Language Studies, Faculty of Training Technology \\ University of Vocational Technology, Sri Lanka \\ nandulap@univotec.ac.lk
}

\begin{abstract}
Sri Lankan English (SLE) is recognized as an independent and unique variety of English. Since the introduction of English to Sri Lanka in 1796, its vocabulary has undergone a steady change. The current study is a trend analysis of the SLE vocabulary seen in journalistic writing. It is conducted through a content analysis and a comparative study. The data is extracted from selected newspaper articles of 1955-1965 and 2005-2015. A total of 44 newspaper pages were used for the study. The data is compared to identify the developing trends in the vocabulary used over a period of 60 years in the country. The data showed that the composition of the vocabulary of English in Sri Lanka has changed over the years. Some words have been dropped from usage and are considered archaic at present, while new vocabulary items have come into use. In the period under examination, there is an increase in the number of words that could be identified as 'SLE vocabulary'. Many word formation processes are commonly used to create the new SLE terms that are added to the language.
\end{abstract}

Keywords: Sri Lankan English, trend analysis, vocabulary, composition, word formation processes 


\section{Introduction}

The present study documents the current trends in the Sri Lankan English (SLE) vocabulary as seen in the journalistic writing from 2005-2015. Fernando (2012) identifies vocabulary as an aspect that clearly reflects the changes in a language. SLE vocabulary displays a change in form and composition over the past few decades.

Research on SLE phonology has been conducted by C. Fernando (1976), S. Fernando (1985), Gunesekera (2005) and Wijetunge (2008). Gunesekera (2005) has studied SLE syntax, while SLE morphology has been studied by Fernando (2012), Gunesekera (2005) and Meyler (2011). However, apart from the linguistic characteristics identified and explored by the above researchers, the recent trends in SLE vocabulary as found in newspapers are not studied in detail. The significance of the present study is that it has analyzed journalistic writing as a specific genre of SLE writing with the objective of documenting any emerging trends in the SLE vocabulary in the said genre. Hence, the objective of the present study is to compare the vocabulary of Ceylon Observer from 1955-1965 with the Sunday Observer from 2005-2015, and thereby document any developing trends seen in the vocabulary, that are different to the ones identified by the previous researchers. Since the data is obtained from the decade 2005-2015, this study could contribute to update the existing records of SLE vocabulary analysis.

Thus, the research was conducted to answer the following research question

RQ: In a comparative study of the SLE vocabulary in newspapers from 19551965 and 2005-2015, what are the observable trends in vocabulary development?

\section{Literature review}

\section{Evolution Models of New Englishes}

Several theories of language evolution and its stages have been put forward by linguists, which are useful for the present study. Kachru (1992) identifies four stages of development in the "non-native institutionalized varieties of English" (p.56). They are "non-recognition of the local variety", "extensive diffusion of bilingualism in English" which leads to the "development of varieties within a 
variety", non-native variety being accepted as a norm and finally the recognition of the variety (Kachru, 1992, pp. 56, 57). Schneider (2003) identifies "Foundation, Exonormative Stabilization, Nativization, Endonormative Stabilization and Differentiation" (p.243) as stages of language evolution. SLE has undergone most, if not all, of these stages of evolution and the variety has become increasingly Lankanized (Kachru, 1992, p.56). It has now reached a "national standard" (Gunesekera, 2005, p.128).

Fernando (2012) identifies three stages of SLE development. The first is the period after 1796, where English was exposed to social and political pressures from the local languages, and the locals as well as the British had to innovate words to express the "social, economic, geographical, cultural novelties" of the island (Fernando, 2012, p.162). The second is the "post-independence period" (Fernando, 2012, p. 165, p. 164) when the language started to shift from being the English of the "colonizer" to the English of the "once colonized" (Gunesekera, 2005, p. 20). The third stage is termed the "contemporary period" (Fernando, 2012, p. 165) where an increasing number of speakers used SLE as a second language. This is roughly the period where English was restored to the status of one of the official languages, and at a later point, attributed the state of the link language (Gunesekera, 2005, p. 17). Currently, SLE, specifically its vocabulary, continues to expand, and represents features different from those codified in the work of Gunesekera (2005) and Meyler (2011).

Against a backdrop of rapid change, in the context of World Englishes and Sri Lankan Englishes, there is a need for genre specific vocabulary analyses of SLE. The present study focusing on the journalistic writing over the decade 2005-2015 attempts to fill this gap.

\section{Sri Lankan Englishes}

SLE is branching off into new varieties. Gunesekera (2005) broadly divides SLE as the standard variety and the non-standard variety depending on the social status and the degree of familiarity with the language (p.35). Other SLE varieties are defined by race and ethnic group, religion, age and the social status of the speakers. 
These varieties have influenced one another (Gunesekera, 2005, p.127). As Meyler (2011) says:

[W]ithin the relatively tiny English-speaking community, there are several subvarieties of Sri Lankan English. Sinhalese, Tamils, Muslims and Burghers speak different varieties; Christians, Buddhists, Hindus and Muslims have their own vocabularies; the older generation speak a different language from the younger generation; and the wealthy Colombo elite (who tend to speak English as their first language) speak a different variety form the wider community (who are more likely to learn it as a second language. (p.xi)

For a more descriptive representation of the Sri Lankan Englishes, detailed codification of each variety is essential. The present study is limited to the register of journalistic writing and is an attempt to analyze the recent SLE vocabulary of the said register.

\section{Present Study}

Stating the necessity to continue studies on SLE vocabulary, Gunesekera (2005) writes, "[m]uch more research needs to be done for a thorough listing of the words and phrases of Sri Lankan English" (p.154). Also, Fernando (2012) states that the linguistic studies of the $21^{\text {st }}$ Century should focus on "exploring the linguistic pressures and counter pressures giving rise to the future development of SLE vocabulary" (p.177). Three years after the launch of the first edition of $A$ Dictionary of Sri Lankan English, Meyler (2010) points out the need for documenting the rapid changes in SLE saying; "in 10 years' time, who knows how the language might have changed?". Hence, SLE research needs to be revised and updated to understand the progressive nature of SLE.

The present study compares the vocabulary of newspapers from 1955-1965 and 2005-2015, and records the emerging trends in SLE vocabulary, thereby attempting to answer the research question stated in the Introduction. 


\section{Methodology}

SLE vocabulary could be extracted for research from a number of sources. Meyler (2011) uses books published between 1982 and 2006 to obtain his data (p.xxxiii) while Gunesekera (2005) records words extracted from "conversations among Sri Lankans" which "represent real life usage" (p.161). For the current research, 22 newspapers of Ceylon Observer ${ }^{1}$ from 1955-1965 and 22 newspapers of Sunday Observer $^{2}$ from 2005-2015 were used. Hence, data was gathered from 44 newspaper pages for the study.

The data collection method is a combination of random sampling and purposive sampling. Two newspapers for each year were selected randomly. The newspapers from 1955-1965 were obtained from the Department of National Archives, Sri Lanka and the newspapers from 2005 - 2015 were obtained from the Sunday Observer website (www.sundayobserver.lk) ${ }^{3}$. From each newspaper, the articles in the first page and the editorial were used for the study. In the case of online versions, the articles on the home page and the editorial were selected. These criteria make the articles a purposive sample, which according to Dörnyei is "a sampling plan describing the sampling parameters (participants, settings, events, processes), and [which] lines up with the purposes of the study" (Dörnyei, 2007, p.97, p. 126). Once the first page is selected, the SLE words in the page were extracted. To identify if a certain word could be considered SLE, the linguistic knowledge and the experience of the researcher and a colleague who are both native speakers of SLE was used. This was to ensure objectivity in the process of categorizing a word as SLE.

\footnotetext{
1 Ceylon Observer was the name used for Daily News and Sunday Observer at the start of the Newspaper in 1834.

2 Sunday Observer is the Sunday newspaper of the Daily News. Ceylon Observer, Daily News and Sunday Observer are state publications published by the Associated Newspapers Ceylon Limited.

${ }^{3}$ The online newspaper and the printed newspaper contain the same articles.
} 


\section{Results and Discussion: trends in SLE vocabulary}

(Analysis of vocabulary from Ceylon observer and Sunday observer)

As seen in the table below, the number of SLE words have increased in the dataset of 2005-2015.

Table 1: Number of SLE words in the articles from 1955-1965 and 2005-2015

\begin{tabular}{|l|c|}
\hline Newspaper & Number of SLE words \\
\hline Ceylon Observer $1955-1965$ & 37 \\
\hline Sunday Observer $2005-2015$ & 110 \\
\hline
\end{tabular}

This indicates an increased Sri Lankanness in the vocabulary over the past 60 years. Compared to the dataset of 1955-1965, the number of SLE words has increased roughly by three times.

In addition, some words used in the period 1955-1965 were absent in the period 2005-2015. They are mentioned below with examples.

\section{Words with French origin}

Communique, Epaulette, Cortege, Tour de Lanka were words of French origin that were used in the articles from 1955 to 1965 . From 2005 to 2015, the data did not indicate any usages of words with French Origin.

\section{Idioms from literary texts and biblical allusions}

British English idioms, especially those extracted from literary texts and the Bible were found in the articles of 1955 - 1965. 'Milk of human kindness', 'Manna from heaven', 'Jekyll and Hyde' could be mentioned as examples. Such idioms were not found in the decade $2005-2015$.

As seen from the data, the language of the decade from 1955 to 1965 consisted of vocabulary that Halverson (1966) termed "latinate" (p.72). However, in the decade 2005-2015, the data did not contain any such phrases / idioms. As the dataset is a sample of the writing in newspapers, it can be stated that the usage of Latinate terms in SLE vocabulary has become less frequent by 2005-2015. 
Apart from these, the other morphological features of the SLE vocabulary seen in journalistic writing are analyzed below.

\section{SLE vocabulary in journalistic writing}

A morphological analysis of the data gathered is given below. The complete list of examples for each word formation category is given in Appendix 1 (Vocabulary from 1955 - 1965) and Appendix 2 (Vocabulary from 2005 - 2015).

\section{Compounds}

Fernando (2012) identifies self-explaining compounds as a common word formation strategy in new varieties of English (p.166). Gunesekera (2010) also identifies compounding as a "tendency of South Asian Englishes in word formation" (p.203). Over the 60 years under examination, the number of SLE compounds has increased significantly, from 12 to 31 examples. SLE compounds such as 'Mahinda Chinthanaya', 'Maithri Palanaya' and 'Mother Lanka' reflect the political climate of the country, 'Aloka Pooja' refers to religious practices while 'seeni sambol' refers to a food item. Fernando, in 2012, observed that the SLE vocabulary reflects the social and political climate of the country. This is evident in the compounds of the date set from 2005-2015. Some examples are given in the table below.

\section{Table 2: Compounds}

\begin{tabular}{|l|l|}
\hline \multicolumn{1}{|c|}{ 1955-1965 } & \multicolumn{1}{c|}{ 2005-2015 } \\
\hline Bottle Lamp & Mahinda Chinthanaya \\
\hline Buddha Jayanthi & Seeni Sambol \\
\hline Diyawardane Nilame & Aloka Pooja \\
\hline Air Ceylon & Thoppigala Jungles \\
\hline Radio Ceylon & Rajapaksa regime \\
\hline Vidyalankara University & Bodu Bala Sena \\
\hline
\end{tabular}




\begin{tabular}{|l|l|}
\hline Devil Dancer & Maithri Palanaya \\
\hline Ceylon Medical Council & Ethnic Tamil \\
\hline Ran Veta & Lalith Athulathmudali Vidyalaya \\
\hline Vesak Lanterns & Api Wenuwen Api \\
\hline
\end{tabular}

\section{Borrowings}

The complexity and the diversity in the SLE borrowings of the two datasets required a detailed classification rather than a broad division into direct borrowings and indirect borrowings. Thus, the categorization made by Fernando (2012) was used as a guide in the present analysis.

\section{Loanwords}

Loanwords are similar to "direct borrowings" (Akmajian, Demers, Farmer \& Harnish, 2001, p.27). A loanword displays "phonemic substitution" but not “morphemic substitution" (Fernando, 2012, p.170). Haugen (1950) states that a loanword may contain "no, partial or complete phonemic substitution" (as cited in Fernando, 2012, p.170). Loanwords were abundant in the SLE vocabulary used in journalistic writing. Some examples are given below.

Table 3: Loanwords

\begin{tabular}{|l|l|l|l|}
\hline \multicolumn{2}{|c|}{$1955-1965$} & \multicolumn{2}{c|}{2005 - 2015} \\
\hline Loanword & $\begin{array}{l}\text { Languages from which } \\
\text { the words are drawn }\end{array}$ & Loanword & $\begin{array}{l}\text { Languages from } \\
\text { which the words } \\
\text { are drawn }\end{array}$ \\
\hline Hartal & Arabic & Murrukku & Tamil \\
\hline Kachcheri & Tamil & Eelam & Thai English \\
\hline Ayrveda & Sanskrit & Tuk tuk & \\
\hline
\end{tabular}

Contd. 


\begin{tabular}{|c|c|c|c|}
\hline Satyagraha & & Anthare & \multirow{6}{*}{ Sinhala } \\
\hline Dana & \multirow{2}{*}{ Pali } & Avrudu & \\
\hline \multirow[t]{4}{*}{ Sangha } & & Senkadagala & \\
\hline & & Balasena & \\
\hline & & $\begin{array}{l}\text { Gama } \\
\text { Neguma }\end{array}$ & \\
\hline & & Yahapalanaya & \\
\hline
\end{tabular}

Loanwords seem to have been popular in SLE vocabulary over the years and have increased in number. The study encountered only 8 loanwords from 1955 - 1965 and 29 from 2005 - 2015. As seen in the examples given above, the loanwords refer to the "flora and fauna of the country, to different types of food and drink, and to Buddhism, the majority religion of the country" (Meyler, 2009, p.57). The word 'tuk tuk' is used to refer to the trishaw and is a borrowing from Thai English (Hashim \& Bennui, 2014, p.135). SLE has been enriched with loanwords from Tamil, Hindi, Malay, Arabic, Dutch, Portuguese and other Languages (Meyler, 2009, p.57). The loanwords in the dataset 2005-2015 such as Eelam, Gama Naguma, Maga Naguma, Uthuru Wasanthaya, Nagenahira Navodaya, Divinaguma, Yahapalanaya and Anthare reflect the political climate of the country. Such political references were less in the journalistic writing from 19551965.

\section{Blended Stems}

Blended stems are a type of borrowing, and Haugen (1950) defines them as instances where "inflectional suffixes and stems from two different languages are blended in a new variety" (as cited in Fernando, 2012, p.173). Gunesekera (2010) identifies blends in which a "borrowing from an indigenous language [is] suffixed with the plural marker $-\mathrm{s}$ ", as a "morphological phenomenon of Sri Lankan English" (p.206). Given below are examples of blended stems. 
Table 4: Blended Stems

\begin{tabular}{|l|l|l|l|}
\hline \multicolumn{2}{|l|}{$1955-1965$} & \multicolumn{2}{c|}{2005 - 2015 } \\
\hline $\begin{array}{l}\text { Blended } \\
\text { Stem }\end{array}$ & $\begin{array}{l}\text { Meaning in } \\
\text { Context }\end{array}$ & Blended Stem & Meaning in Context \\
\hline Sinhalese & Sinhala Language & Mahanayakas & $\begin{array}{l}\text { The Mahanayaka } \\
\text { Theros } \\
\text { of the Malwathu and } \\
\text { Asgiri Chapters }\end{array}$ \\
\hline Mudalalies 5 & $\begin{array}{l}\text { People who own buses in } \\
\text { the private bus service } \\
\text { of Sri Lanka }\end{array}$ & JVPers & $\begin{array}{l}\text { Supporters of the } \\
\text { Janatha Vimukthi } \\
\text { Peramuna }\end{array}$ \\
\hline Panas & $\begin{array}{l}\text { Small oil lamps made out } \\
\text { of clay }\end{array}$ & UNPers & $\begin{array}{l}\text { Supporters of the } \\
\text { United National Party }\end{array}$ \\
\hline Satyagrahis & $\begin{array}{l}\text { People who engage in } \\
\text { a 'satyagaha' (Protest) }\end{array}$ & & \\
\hline
\end{tabular}

\section{Blended Compounds}

This is a compound created out of a borrowing, and are formed by blending "two or more stems from different languages" (Fernando, 2012, p. 173). Blended compounds, also called "hybrid compounds", are very commonly seen in SLE vocabulary (Fernando, 2012, p. 173).

\footnotetext{
4 The word Sinahlese in the given context meant the Sinhala Language and not the Sinhala Race. Hence the suffix 'ese' is added to the word 'Sinhala' to create the blended stem.

${ }^{5}$ The word Mudalalies has a derogatory connotation
} 
Table 5: Blended

\begin{tabular}{|c|c|c|c|}
\hline \multicolumn{2}{|c|}{$1955-1965$} & \multicolumn{2}{|c|}{$2005-2015$} \\
\hline $\begin{array}{l}\text { Blended } \\
\text { Compound }\end{array}$ & $\begin{array}{l}\text { Formation of } \\
\text { the Blended } \\
\text { Compound }\end{array}$ & $\begin{array}{l}\text { Blended } \\
\text { Compound }\end{array}$ & $\begin{array}{l}\text { Formation of the Blended } \\
\text { Compound }\end{array}$ \\
\hline $\begin{array}{l}\text { Sinhala } \\
\text { Culture }\end{array}$ & $\begin{array}{l}\text { Sinhala }(S)^{6}+ \\
\text { Culture }(E)^{7}\end{array}$ & Mother Lanka & Mother (E)+ Lanka (S) \\
\hline $\begin{array}{l}\text { Sinhala } \\
\text { Christians }\end{array}$ & $\begin{array}{l}\text { Sinhala }(S)+ \\
\text { Christians }(E)\end{array}$ & $\begin{array}{l}\text { Sinha Regiment } \\
\text { Camp }\end{array}$ & $\begin{array}{l}\text { Sinha }(S)+\text { Regiment }(E)+ \\
\text { Camp (E) }\end{array}$ \\
\hline \multirow[t]{6}{*}{$\begin{array}{l}\text { Bus } \\
\text { Mudalalies }\end{array}$} & $\begin{array}{l}\text { Bus }(\mathrm{E})+ \\
\text { Mudalalie (S) }\end{array}$ & $\begin{array}{l}\text { Vijeyaba Infantry } \\
\text { Battalion }\end{array}$ & $\begin{array}{l}\text { Vijeyaba (S) + Infantry }(E)+ \\
\text { Battalion }(E)\end{array}$ \\
\hline & & Bo-Leaves & Bo $(\mathrm{S})+$ Leaves $(\mathrm{E})$ \\
\hline & & Poson Week & Poson $(\mathrm{S})+$ Week $(\mathrm{E})$ \\
\hline & & Malwatta Chapter & Malwatta (S) + Chapter (E) \\
\hline & & Asgiriya Chapter & Asgiriya $(\mathrm{S})+$ Chapter $(\mathrm{E})$ \\
\hline & & Mahajana Faction & Mahajana (S) + Faction (E) \\
\hline
\end{tabular}

Fernando (2012) states that hybrid compounds are a "fairly large" category in SLE (p.173). In fact, the data from 2005-2015 shows that blended compounds have increased in number when compared with the data from the decade 19551965, as new blended compounds were created to express political and war related terms. E.g.: Mahajana Faction, Sinha Regiment Camp.

\section{Loan Translations}

Loan translations are yet another type of borrowings where, as Haugen (1950) says, one could observe morphemic substitution without importation (as cited in Fernando, 2012, p. 174). In the SLE vocabulary, new words are formed by translating the Sinhala compounds into English. In such instances, only the

${ }^{6}(\mathrm{~S})$ stands for Sinhala

${ }^{7}$ (E) stands for English 
meaning of the Sinhala term is carried on to English. Loan translations are also made from Tamil words but the newspaper sample used in the research did not have examples of such usages. Fernando (2012) mentions that in the SLE compound 'ash plantain', the morphemes in the Sinhala compound 'alu kesel' are substituted with two English translation equivalents (p.174). Loan translations taken from the gathered data are given below.

Table 6: Loan Translations

\begin{tabular}{|l|l|l|l|}
\hline \multicolumn{2}{|c|}{1955 - 1965} & \multicolumn{2}{|c|}{2005 - 2015} \\
\hline $\begin{array}{l}\text { Loan } \\
\text { Translation }\end{array}$ & $\begin{array}{l}\text { Comments on } \\
\text { Usage }\end{array}$ & $\begin{array}{l}\text { Loan } \\
\text { Translation }\end{array}$ & Comments on the usage \\
\hline $\begin{array}{l}\text { Devil Dancer } \\
\text { references. The } \\
\text { performer of the } \\
\text { traditional 'Yak } \\
\text { Natuma' }\end{array}$ & $\begin{array}{l}\text { Honourable } \\
\text { Peace }\end{array}$ & $\begin{array}{l}\text { This is a politically loaded term } \\
\text { and a translation from the concept } \\
\text { of 'Gaurawanwitha Saamaya' } \\
\text { which was frequently used by the } \\
\text { former president of Sri Lanka, } \\
\text { Mr. Mahinda Rajapaksa }\end{array}$ \\
\hline Lion Flags & $\begin{array}{l}\text { Translated from } \\
\text { 'Singha Kodi' }\end{array}$ & Triple Gem & $\begin{array}{l}\text { The triple Gem refers to the } \\
\text { Buddha, Dhamma and Sangha } \\
\text { and is used in the extract as a } \\
\text { term to invoke blessings. }\end{array}$ \\
\hline & Trains & $\begin{array}{l}\text { Office } \\
\text { term 'Kāryāla Dumriya' which } \\
\text { means the train used by the } \\
\text { commuters to travel to the } \\
\text { workplaces and back to their } \\
\text { homes. }\end{array}$ \\
\hline
\end{tabular}

Contd. 


\begin{tabular}{|c|c|c|c|}
\hline \multicolumn{2}{|c|}{$1955-1965$} & \multicolumn{2}{|r|}{$2005-2015$} \\
\hline $\begin{array}{l}\text { Loan } \\
\text { Translation }\end{array}$ & $\begin{array}{l}\text { Comments on } \\
\text { Usage }\end{array}$ & $\begin{array}{l}\text { Loan } \\
\text { Translation }\end{array}$ & Comments on the usage \\
\hline & & $\begin{array}{l}\text { Wonder of } \\
\text { Asia }\end{array}$ & $\begin{array}{l}\text { The borrowing from the Sinhala } \\
\text { Term 'Āsiyawe Āshcharya' } \\
\text { which was used by the former } \\
\text { president, Mr. Mahinda } \\
\text { Rajapaksa to define his vision for } \\
\text { the county according to his } \\
\text { election manifesto. }\end{array}$ \\
\hline & & $\begin{array}{l}\text { Compassion } \\
\text { ate Rule }\end{array}$ & $\begin{array}{l}\text { This is another borrowing from } \\
\text { the political arena, used by Mr. } \\
\text { Maithripala Sirisena as the tagline } \\
\text { of his presidential election } \\
\text { campaign. The loan translation } \\
\text { stems from the Sinhala compound } \\
\text { 'Maithri Pālanya'. }\end{array}$ \\
\hline & & $\begin{array}{l}\text { North -East } \\
\text { Problem }\end{array}$ & $\begin{array}{l}\text { This is a translation from the } \\
\text { Sinhala usage 'Uthuru } \\
\text { Nagenahira Prashnaya' }\end{array}$ \\
\hline & & $\begin{array}{l}\text { Tiger } \\
\text { Terrorists }\end{array}$ & $\begin{array}{l}\text { The Sinhala usage of the term is } \\
\text { 'Koti Thrsthawadin' }\end{array}$ \\
\hline & & Lion Flag & $\begin{array}{l}\text { Used in reference to the National } \\
\text { Flag and the translation of the } \\
\text { Sinhala term 'Singha Kodiya' }\end{array}$ \\
\hline
\end{tabular}

According to the definition of loan translations by Fernando (2012), and the examples provided above, it is seen that loan translations capture a specific concept in Sinhala and transports it to English. They may appear to be self- 
explanatory compounds but they connote unique meanings in the Sri Lankan social, cultural and political spheres.

In the SLE vocabulary of journalistic writing, the number of loan translations with political connotations have increased significantly from 1955-1965 and this could be viewed as a characteristic of the expanding SLE vocabulary. Fernando (2012) states:

In the contemporary period, when new dialects of SLE developed, there were changes and additions to the SLE vocabulary. The mood in Sri Lanka had become more complex, as it passed through times of racial and class tensions, conflict, war, economic and social, corruption, natural disasters, rehabilitation, peace and reconciliation etc. Words representing these changes in mood have been reflected in SLE vocabulary. (p. 165)

Thus, loan translations are a creative category in the SLE vocabulary which is constantly updated and some loan translations last longer than others. Words such as 'Triple Gem' and 'office trains' have a greater possibility of retention than words such as 'honourable peace' or 'compassionate rule'. Nevertheless, they are unique expressions of the Sri Lankan experience.

The number of borrowings from the decade 1955-1965 was 15 while the decade from 2005 - 2015 had 47 borrowings. According to Fernando (2012), Sinhala and Tamil borrowings in SLE vocabulary have become fashionable since the independence (p.172). The two datasets confirm this observation by Fernando (2012). 


\section{Affixation of Compounds}

The data gathered contained a few interesting examples of affixation.

Table 7: Affixation of compounds

\begin{tabular}{|l|l|}
\hline $\begin{array}{l}\text { Compound + Affixation } \\
(\mathbf{1 9 5 5}-\mathbf{1 9 6 5 )}\end{array}$ & $\begin{array}{l}\text { Compound + Affixation } \\
(\mathbf{2 0 0 5 - 2 0 1 5})\end{array}$ \\
\hline Bus Mudalalies & Bus Mudalalis \\
\hline Little pol-thel panas & Maha Nayake Theras \\
\hline
\end{tabular}

\section{Initialisms and Clippings}

Initialisms and clippings are used to form new words through abbreviations.

\section{Initialisms}

Initialisms are also called alphabetic abbreviations (Akmajian et al., 2001, p. 26) and each of the letters that spell the initialism is the first letter or letters of a set of words (Akmajian et al., 2001, p.25). These letters of the initialism are individually pronounced (Akmajian et al., 2001, p. 26). SLE vocabulary in newspapers consisted of initialisms which are used considerably frequently both in writing and in speech.

Table 8: Initialisms

\begin{tabular}{|l|l|l|l|}
\hline \multicolumn{2}{|c|}{1955 - 1965} & \multicolumn{2}{c|}{2005 - 2015} \\
\hline Initialism & Meaning & Initialism & Meaning \\
\hline SLFP & $\begin{array}{l}\text { Sri Lanka } \\
\text { Freedom Party }\end{array}$ & LTTE & $\begin{array}{l}\text { Liberation Tigers of Tamil } \\
\text { Eelam }\end{array}$ \\
\hline LSSP & $\begin{array}{l}\text { Lanka Sama } \\
\text { Samaja Party }\end{array}$ & SLFP-UNP & $\begin{array}{l}\text { Sri Lanka Freedom Party - } \\
\text { United National Party }\end{array}$ \\
\hline FP & Federal Party & BIA & $\begin{array}{l}\text { the Bandaranaike International } \\
\text { Airport }\end{array}$ \\
& & & \\
\hline
\end{tabular}




\begin{tabular}{|l|l|l|l|}
\hline \multicolumn{2}{|c|}{1955 - 1965} & \multicolumn{2}{c|}{2005 - 2015 } \\
\hline Initialism & Meaning & Initialism & Meaning \\
\hline \multirow{2}{*}{} & LLRC & $\begin{array}{l}\text { Lessons Learnt and } \\
\text { Reconciliation Commission }\end{array}$ \\
\cline { 2 - 4 } & MRIA & $\begin{array}{l}\text { Mattala Rajapaksa International } \\
\text { Airport }\end{array}$ \\
\hline
\end{tabular}

The articles during the 2005-2015 decade contained 17 Initialisms while the 19551965 decade had only 6. Also, Initialisms related to war and politics were commonly used in the journalistic writing of the decade 2005 - 2015. New projects initiated by the government were referred to by initialisms and it was frequently found in the newspapers from 2005 to 2015. The type of initialisms found in each decade represents the socio-political condition of the country at the time.

\section{Clippings}

Clippings are formed by shortening a word, E.g. Using 'prof' for 'professor' (Akmajian et al., 2001, p. 26). Clippings were not common in the articles that were analyzed and were found only in the articles from the decade 2005 - 2015. The following are examples from the data gathered.

Table 9: Clippings (Found in the articles from 2005 to 2015)

\begin{tabular}{|l|l|l|l|}
\hline Date of Newspaper & Clipping & Extract from newspaper & $\begin{array}{l}\text { Meaning of the } \\
\text { acronym }\end{array}$ \\
\hline $\begin{array}{l}\text { Sunday Observer, } \\
\text { Sunday } 24^{\text {th }} \text { May } \\
2009\end{array}$ & Prabha & $\begin{array}{l}\text { Who supported Prabha to } \\
\text { fight a sovereign State? }\end{array}$ & $\begin{array}{l}\text { Velupillai } \\
\text { Prabhakaran, the } \\
\text { leader of the LTTE. }\end{array}$ \\
\hline $\begin{array}{l}\text { Sunday Observer, } \\
\text { Sunday } 27^{\text {th }} \text { October } \\
2013\end{array}$ & Varsities & $\begin{array}{l}\text { Varsities to shift to } \\
\text { student-centred }[\text { sic }]\end{array}$ & Universities \\
learning... & \\
\hline
\end{tabular}




\section{Semantic Change}

Semantic change in the SLE vocabulary occurs when "English words take on a different meaning although the words remain unchanged" (Gunesekera, 2005, p.152). Semantic change was observed in the journalistic writing from 2005 to 2015. Most of the terms with semantic change have appropriated political connotations which might be context specific and arbitrary, as they have been produced in unique socio-cultural contexts.

Table 10: Semantic Change (Found in the articles from 2005 to 2015)

\begin{tabular}{|c|c|c|c|}
\hline Newspaper & $\begin{array}{l}\text { Semantic } \\
\text { Change }\end{array}$ & $\begin{array}{l}\text { Comment on the use } \\
\text { of word }\end{array}$ & Extract from newspaper \\
\hline $\begin{array}{l}\text { Sunday Observer, } \\
\text { Sunday } 29^{\text {th }} \\
\text { October } 2006\end{array}$ & North & $\begin{array}{l}\text { The term 'North' not } \\
\text { only means the } \\
\text { Northern province but } \\
\text { also the people of the } \\
\text { North and their } \\
\text { concerns }\end{array}$ & $\begin{array}{l}\text { The opposition Leader Ranil } \\
\text { Wickremasinghe too deserves } \\
\text { a bouquet for extending the } \\
\text { support of his party to the } \\
\text { Government at a juncture the } \\
\text { South needs unity and } \\
\text { consensus to negotiate with } \\
\text { the North. }\end{array}$ \\
\hline $\begin{array}{l}\text { Sunday Observer, } \\
\text { Sunday } 29^{\text {th }} \\
\text { October } 2006\end{array}$ & Mahawa & $\begin{array}{l}\text { A train going to } \\
\text { Mahawa }\end{array}$ & $\begin{array}{l}\text { With much surprise to the } \\
\text { passengers, the Mahawa, that } \\
\text { was announced as cancelled } \\
\text { earlier, arrived at Gampaha } \\
\text { sans passengers. }\end{array}$ \\
\hline $\begin{array}{l}\text { Sunday Observer, } \\
\text { Sunday } 21^{\text {st }} \\
\text { October } 2008\end{array}$ & Tiger Den & $\begin{array}{l}\text { This term is expanded } \\
\text { to mean the LTTE } \\
\text { Headquarters }\end{array}$ & $\begin{array}{l}\ldots \text { he could not halt the } \\
\text { advancing Security Forces } \\
\text { who are closing in on the } \\
\text { Tiger den... }\end{array}$ \\
\hline
\end{tabular}

Contd. 


\begin{tabular}{|l|l|l|l|}
\hline Newspaper & $\begin{array}{l}\text { Semantic } \\
\text { Change }\end{array}$ & $\begin{array}{l}\text { Comment on the use } \\
\text { of word }\end{array}$ & Extract from newspaper \\
\hline $\begin{array}{l}\text { Sunday Observer, } \\
2015\end{array}$ & $\begin{array}{l}\text { White } \\
\text { Van }\end{array}$ & $\begin{array}{l}\text { The term suggests the } \\
\text { abductions which are } \\
\text { said to have been } \\
\text { done using white } \\
\text { vans }\end{array}$ & $\begin{array}{l}\text { Definitely this white van } \\
\text { concept was orchestrated by } \\
\text { the previous government. }\end{array}$ \\
\hline $\begin{array}{l}\text { Sunday Observer, } \\
\text { Sunday } 13^{\text {th }} \text { April }\end{array}$ & Lions & $\begin{array}{l}\text { Used to refer to the } \\
\text { Sri Lankan Cricket } \\
\text { team }\end{array}$ & $\begin{array}{l}\text {...it provided a better option } \\
\text { for the lions to beat the West } \\
\text { Indies in the semifinals. }\end{array}$ \\
\hline
\end{tabular}

\section{Archives}

This section contains the vocabulary which was found in the articles from 1955 1965. At present, they are hardly used while some of them are no longer in use. These are mostly English words which reflect the Sri Lankan society of the 1950s and were used in context-specific meanings.

Table 11: Archives (Found in the articles from 1955 to 1965)

\begin{tabular}{|l|l|l|l|}
\hline Newspaper & $\begin{array}{l}\text { Archival } \\
\text { words } \\
\text { Sunday 5 }\end{array}$ & $\begin{array}{l}\text { Comment on the use of } \\
\text { word }\end{array}$ & $\begin{array}{l}\text { Extract from } \\
\text { newspaper }\end{array}$ \\
\hline 1956, p.1 & Ceylonese & $\begin{array}{l}\text { Ceylonese is replaced by } \\
\text { 'Sri Lankan' in the } \\
\text { present day. }\end{array}$ & $\begin{array}{l}\text { The plan will have a } \\
\text { "christening" ceremony } \\
\text { and suitable Ceylonese } \\
\text { names are being } \\
\text { considered. }\end{array}$ \\
\hline $\begin{array}{l}\text { Ceylon Observer, } \\
\text { Sunday } 5^{\text {th }} \text { February } .1\end{array}$ & Bazaar & $\begin{array}{l}\text { Bazaar is replaced by } \\
\text { terms such as } \\
\text { 'marketplace' or even the } \\
\text { Sinhala term 'pola'. }\end{array}$ & $\begin{array}{l}\text { But in the bazaar, stalls } \\
\text { occupied by Sinhalese } \\
\text { merchants were } \\
\text { profusely decorated } \\
\text { with Lion flags. }\end{array}$ \\
\hline
\end{tabular}

Contd. 


\begin{tabular}{|l|l|l|l|}
\hline Newspaper & $\begin{array}{l}\text { Archival } \\
\text { words } \\
\text { Saturday 28 }\end{array}$ & $\begin{array}{l}\text { Comment on the use of } \\
\text { word }\end{array}$ & $\begin{array}{l}\text { Extract from } \\
\text { newspaper }\end{array}$ \\
\hline September 1963, p.1 & Beedi & $\begin{array}{l}\text { This term was found in an } \\
\text { advertisement. Beedi was } \\
\text { a cheaper version of } \\
\text { cigarettes. Its popularity } \\
\text { has reduced and at present } \\
\text { it is hardly advertised on a } \\
\text { newspaper. }\end{array}$ & Rajah Beedi Special \\
\hline $\begin{array}{l}\text { Ceylon Observer, } \\
\text { Faturday 1 } 1^{\text {st }}\end{array}$ & Ceylon & $\begin{array}{l}\text { This term is replaced by } \\
\text { 'The Government of Sri } \\
\text { Government }\end{array}$ & $\begin{array}{l}\text { Lord Mountbatten will } \\
\text { be the guest of the } \\
\text { Ceylon Government for }\end{array}$ \\
\hline
\end{tabular}

These terms have decreased in use and have been replaced by new, SLE words. E.g. The use of 'pola' instead of 'bazaar'. 'Ceylon' was changed to 'Sri Lanka' after the year 1972, when the country became a republic. These examples show that the SLE vocabulary of the journalistic writing in Sri Lanka has changed over the past 60 years.

\section{Conclusion}

In answering the initial research question, after a comparative study of the SLE vocabulary in newspapers from 1955-1965 and 2005-2015 several tends in SLE vocabulary development were identified.

Within the sample of the study, the vocabulary of the decade 2005-2015 could be termed more 'Sri Lankan' than that of the decade 1955-1965. In the genre of journalistic writing, the number of SLE words have increased from 37 to 110 and there is a decrease in words of French origin, idioms and biblical allusions. New SLE words are coined using several word formation rules. The most common trends observed in SLE word formation were compounding, loan words, initialisms and semantic change. Within the sample, over 60 years, the number of 
compounds has increased from 12 to 31 , while the number of loanwords has increased from 8 to 29 . The number of initialisms has increased from 6 to 17 , with 14 words with semantic change in the decade 2005-2015 as opposed to none in the decade 1955-1965.

As Künstler, Mendis, \& Mukherjee (2010) observe:

[T]he English language has also been adapted to the sociocultural context of Sri Lanka. Drawing an analogy to Kachru's (1983) concept of the 'Indianization' of English in India, one could posit a process of Ceylonization (or Lankanization, for that matter) of English ever since the establishment of British supremacy over the island in 1802 (p.264)

Similarly, it could be concluded that the developing trends in the SLE vocabulary found in journalistic writing have contributed to the increased Lankanization of SLE.

\section{Acknowledgements}

The author would like to thank the staff at National Archives for their support and the colleagues of the Department of English for their input in conducting this research.

\section{References:}

Akmajian, A., Demers, R., Farmer, A., \& Harnish, R. (2001). Linguistics: An introduction to language and communication. 5th ed. Cambridge: The MIT Press. Dörnyei, Z. (2007), Research methods in applied linguistics. Oxford: Oxford University Press.

Fernando, C. (2010). English in Sri Lanka: A case study of a bilingual community. Language and Society, vol.06, 1976, later published in English in Sri Lanka: Ceylon English, Lankan English, Sri Lankan English 211-223. Colombo: SLELTA. 
Fernando, S. (1985). Changes in Sri Lankan English as reflected in phonology. University of Colombo Review, vol.05, 1985. Sri Lanka: University of Colombo. Viewed on 17 October 2015, http://archive.cmb.ac.lk/research/bitstream /70130/3731/1/ changes.pdf.

Fernando, S. (2012). Sri Lankan English (SLE) vocabulary: A new vocabulary in a new variety of English. VISTAS: Journal of Humanities \& Social Sciences, 7 (8), 160-179.

Gunesekera, M. (2005). The postcolonial identitiy of Sri Lankan English Colombo: Katha Publishers.

Gunesekera, M. (2010). Discourse on governance: Changing trends. English in Sri Lanka: Ceylon English, Lankan English, Sri Lankan English. Colombo: SLELTA. 198-207.

Halverson, J., (1966). Prolegomena to the study of Ceylon English. University of Ceylon Review, 24 (1/2), 61-75.

Hashim, A., \& Bennui, P. (2014), viewed 25 October 2015, Lexical creativity in Thai English fiction. Kritika Kultura, 21/22, 132 - 163. http:// kritikakultura. ateneo.net/ images/ pdf/ KK\%2021-22/21\%20 Lexical\%20

Creativity.pdf

Kachru, B. B. (1992). Models for non-native Englishes. In B.B. Kachru (Eds.), The other tongue: English across cultures (2nd ed.) (pp.48-74). Chicago, IL: University of Illinois Press.

Künstler, V., Mendis, D., \& Mukherjee, J. (2010). English in Sri Lanka: Language functions and speaker attitudes. English in Sri Lanka: Ceylon English, Lankan English, Sri Lankan English. 264-284.

Meyler, M. (2009). Viewed 11 September 2015, Sri Lankan English: a distinct South Asian variety: Identifying and describing Sri Lankan English. English Today 100, 25 (4), 55-60. http://mirisgala.net/PDF/English_Today_Article.pdf 
Meyler, M. (2010). 'Sri Lankan English: The state of the debate'. In: Groundviews: Journalism for Citizens. Retrieved from http://groundviews.org/ 2010/04/27/sri-lankan- english-the-state-of-the-debate/. Accessed on 11th September 2015.

Meyler, M. (2011). A Dictionary of Sri Lankan English (3rd ed.). mirisgala.net: Michael Meyler.

Schneider, E.W. (2003). The dynamics of New Englishes: From identity construction to dialect birth. Language, 79 (2), 233-281.

Wijetunge, S.N. 2008. Viewed 5 September 2015. The stigma of "Not Pot English" in Sri Lanka: A study of production of /o/ and /O/ and implications for instructions. In: Applied linguistics and english as a second language theses. Retrieved from http://scholarworks.gsu.edu/alesl_theses/1 